\title{
CIVIL AND MILITARY AIRWORTHINESS CHALLENGES IN ASIA
}

\author{
Chow Vi THIAN \\ School of Aerospace Mechanical and Manufacturing Engineering, \\ RMIT University, Melbourne, Australia \\ Association of Asia Pacific Airlines, Kuala Lumpur, Malaysia \\ E-mail:s3161423@student.rmit.edu.au
}

Received 12 March 2014; accepted 8 May 2015

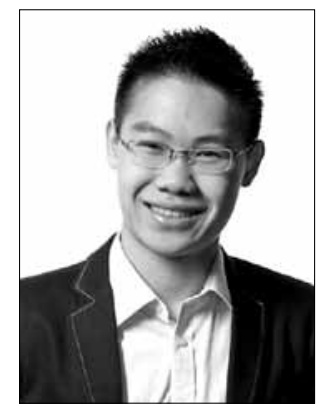

\begin{abstract}
Chow Vi THIAN
Date of birth: 1988

Education: 2007-2010 - Bachelor of Applied Science (Aviation), RMIT University, School of Aerospace Mechanical and Manufacturing Engineering.

Affiliations and functions: since 2007, Member of the Royal Aeronautical Society, since 2013, Member of the Flight Safety Foundation.

Research interests: the effects of growth on the aviation industry in the Asia-Pacific region. Present position: since 2011 Senior Associate for Technical Affairs at the Association of Asia Pacific Airlines.
\end{abstract}

\begin{abstract}
Aviation is one of the most regulated industries in the world. The massive expansion and growth of aviation in the South-East Asia region has brought up many challenges in ensuring airworthiness of aircraft, both in the civil and military aviation domain. These challenges not only affect the safe operations of aircraft but also result in various issues in the areas of cost, infrastructure, human capital and resources. From the point of view of civil aviation, local authorities in the region have taken several initiatives to tackle these challenges, based on the foundations laid out by the International Civil Aviation Organization (ICAO). When it comes to military aviation, agencies, such as the Directorate General Technical Airworthiness (DGTA) of Malaysia, have initiated the regulation of the compliance of military aircraft operations. There has also been an increased focus on awareness of the importance of airworthiness and safety as well as the development of a risk-based approach which is both proactive and cost-efficient.
\end{abstract}

Keywords: civil aviation, military aviation, airworthiness, engineering challenges Asia-Pacific region.

\section{Introduction}

Airworthiness is a process during which an aircraft is deemed suitable for safe flight. In the aviation industry (both civil and military), the airworthiness of an aircraft is highly regulated and operators of aircraft are bound by very specific regulations to ensure the airworthiness of their aircraft (De Florio 2011). The International Civil Aviation Organization (ICAO), as an independent body, under the governing powers of the United $\mathrm{Na}$ tions, drives most of the current civil aviation regulatory framework by setting international standards as well as providing recommendations to all contracting states. ICAO defines airworthiness as all processes that ensure that any given aircraft in its operation lifecycle complies with technical conditions bound by the Certificate of Airworthiness issued by a contracting state to ensure safe operations.
Through ICAO Standards and Recommended Practices (SARPs), ICAO aims to harmonize the safety regulation of civil aviation around the world. However, ICAO SARPs are only applicable to countries signatory to the 1944 Chicago Convention and only to civil aircraft operations (ICAO 2006). ICAO SARPs are to be executed by an individual nation's Civil Aviation Authority (CAA).

In the military domain, there is no complementary international organization providing the same ICAOtype standardization of military aviation regulations; hence, there is less public information and exposure to how military airworthiness is regulated, primarily due to the sensitivities and nature of military aircraft operations (Purton, Kourousis 2013). It is worth noting that currently there is no overarching Military Airworthiness Authority (MAA) across different countries. However, 
there are some countries that have adopted an overarching authority that regulates military aircraft operation in the broad sense (design, engineering, maintenance, flight operations). In most cases, this authority is embedded in the Air Force as a division, but there are also examples of nations that have independent airworthiness authorities reporting directly to the Ministry of Defense or similar. There is also a growing acceptance of military airworthiness regulations being streamlined and harmonised with the civil regulatory requirements, especially in nations that have shared airspace and shared aerodrome operations (Purton et al. 2014a, 2014b, 2014c).

Aircraft airworthiness is undoubtedly very important in ensuring the safe operation of aircraft. All civil and military aircraft are required to comply with the airworthiness standards set by their state airworthiness authority (Civil Aviation Authority or Military) and throughout their operational life must be in a condition of safe operation. Aviation accident data shows that over $20 \%$ of all fatal accidents in aviation are due to airworthiness issues, specifically aircraft mechanical failures (Trew et al. 2013). Ultimately, it is the responsibility of each registered operator to ensure that their aircraft remain in a condition of safe operation, and this is done through both effective management of airworthiness activities and effective programme governance of safety outcomes.

\section{Background}

The Asian aviation environment has experienced a very large boom in recent years due to a rising middle-income segment and the establishment of low cost carriers. The number of aircraft in the region has also been steadily increasing year by year, with Asian airlines setting records for the largest aircraft orders in history. In 2012, within the whole Asia-Pacific region over 948 million passengers have been carried, which accounts for $30 \%$ of global traffic with more than 5,000 aircraft. It is forecast that this number will grow by at least $5 \%$ every year (Herdman 2013).

In the military segment, analysts have forecast that the Asia-Pacific region will experience growth in new aircraft procurement as the region is largely insulated from the economic situation that has impacted North America and Europe, which results in a constant growth in Asia-Pacific economies. Increasing government budgets are also a driving force for both new aircraft purchases and modification plans that can potentially shift the military balance in the region (Frost \& Sullivan 2013).

All this growth has led to an increased challenge for regulators and airworthiness authorities in ensuring aircraft airworthiness and safety. The rise of commercialisation of military aircraft and operations has also brought about new challenges in the defence sector, with the military keen to bridge the gap between military airworthiness standards and civilian airworthiness standards.

There are many guidelines in the civil aviation segment when it comes to regulating airworthiness. To ensure consistent global standards, Civil Aviation Authorities (CAAs) of nations that are subscribed to the Chicago Convention have to adhere to a minimum set of regulations defined by ICAO. Throughout the years, ICAO has been constantly reviewing these regulations in line with the development and growth of civil aviation not only in Asia but worldwide.

The military aviation segment is not able to adopt the same principles laid out by civil aviation due to the nature of its operations and elevated levels of risk involved. Military aircraft deal with non-procedural missions and carry explosive ordinances, which significantly increases the risks of operations, preventing the military from adopting civil aviation regulations as a whole. However, sovereign authorities have the right to ensure that their military aircraft are compliant with civilian requirements when flying or operating in another nation's airspace or when operating in civilian airspace.

\section{Current state in Asia}

ICAO reports that during the period 2006-2010 14\% of commercial flight accidents were due to component or power failures and classifies them under airworthiness issues. Currently, almost all Asian nations set their own airworthiness standards based on ICAO standards and recommendations. However, this is not without its challenges. It can be said that civil and military airworthiness authorities face different challenges but overall there are more similarities than differences.

Rapid aviation growth and expansion in Asia has proved to be a challenge for regulators. As more aircraft take to the skies, regulators are faced with issues such as resource constraints, lack of human capital, inadequate training and commercial pressures.

In most developing nations in Asia, the budget allocated to CAAs is very much dependent on a nation's economic ability. In 2008, The Philippines Civil Aviation Authority (CAAP) has seen the United States Federal Aviation Administration (FAA) downgrade the nation's rating from category 1 to category 2 upon recommendation from ICAO. The downgrade to category 2 indicates that the FAA has assessed that the CAAP has failed to comply with ICAO safety standards for the oversight of air carrier operations (FAA 2013). Although not publicly stated, the failure to comply to SARPs has been blamed on the lack of funds and financial resources due to the economic crisis experienced by the country in 2007 (Eran-Tasker 2013).

Training is a crucial factor for ensuring that airworthiness inspectors are able to perform their tasks 
with a high level of proficiency The challenge encountered in Asia is the situation when the time required to train personnel cannot match the number of aircraft that are used. This is evident in countries such as Malaysia and Indonesia, where the growing low cost market has seen aircraft being delivered from Toulouse and Seattle almost every week. The Department of Civil Aviation (DCA) Malaysia and the Directorate of Civil Aviation (DGCA) Indonesia has been recruiting personnel in numbers however the time taken to get fresh employees up to speed cannot match the number of aircraft delivered (Chew 2013).

\section{Probable and active solutions}

\section{ICAO Universal Safety Oversight Audit Programme (USOAP)}

The ICAO USOAP was established to allow the ICAO Safety Oversight Section to conduct aviation safety oversight audits in an effort to identify deficiencies and encourage their resolution. Launched in 2006, USOAP utilises audits to promote global aviation safety in all ICAO Contracting States.

The objective set out by USOAP is to encourage the promotion of aviation safety through regular audits of Contracting States to determine a state's capability for safety oversight. This is done by assessing the effective implementation of a state's execution of ICAO SARPs, critical elements of safety oversight, guidance material, safety-related procedures and associated practices.

ICAO Annex 8 - Airworthiness of Aircraft - was a key element of the initial USOAP programme and the initial mandate of the programme was to hold an audit for all Contracting States and report to the subsequent session of the ICAO General Assembly every 3 years. Audit follow-ups were then carried out to validate the implementation of the corrective action plans, to identify any other problems associated with the implementation, and to determine if any external assistance is needed to a State.

Looking ahead, a new approach has been embedded into the ICAO USOAP to promote global aviation safety by empowering Contracting States' safety oversight capabilities. This is achieved through a risk-based approach by continuous monitoring of safety performance in order to identify safety deficiencies, assess associated safety risks, and to implement mitigation strategies to minimise these risks.

The ICAO 2013 Safety Report found that the majority of Asian nations have effectively implemented ICAO SARPs above the global average of $61 \%$, with the Republic of Korea achieving the highest score of 99\%, based on USOAP audit results as of December 31, 2012. The global audit results of the effective implementation of safety oversight assesses airworthiness as $73 \%$, the highest among all technical areas as shown in the Figure 1 below.

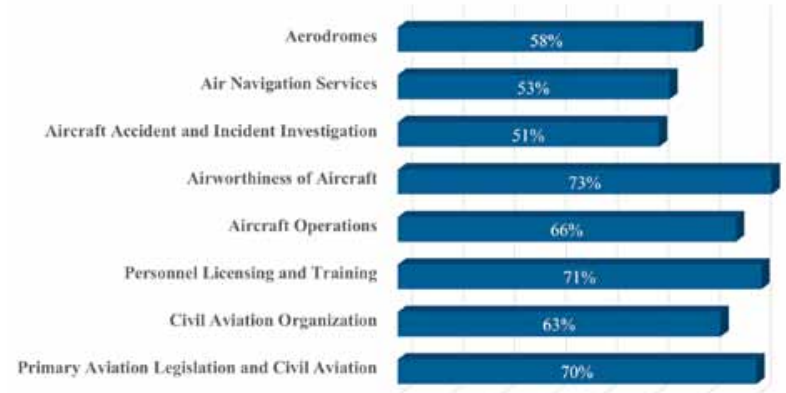

Fig. 1. Global USOAP Audit Results, Effective Implementation of Safety Oversight according to Technical Area in 2012 (adapted from ICAO 2013)

The European Union (EU) common airworthiness framework, namely the European Aviation Safety Agency (EASA), has been an exemplary solution for regulating aviation safety, not only within Europe but at a global level (EASA 2015). Since its inception, this framework has allowed for a harmonised development of regulations and implementation of aviation safety rules across various nations. This has contributed not only to the improvement of aviation safety records but has also enabled greater collaboration between nations in the development and accomplishment of major aeronautical investments and new products (e.g. Airbus export success is attributed partly to EASA regulations and management of the airworthiness product certification process). Many Asian nations have adopted this best practice by mirroring the philosophy and structure of the EASA airworthiness system in practice. Clear advantages and benefits arising out of this support have driven these changes and today EASA is playing a vital role in influencing and formulating the operation of the aviation industry in this key region of the globe. Some examples of Asian countries that have adapted their airworthiness requirements and regulations to the EASA system are provided below (focusing on the aircraft maintenance personnel licensing regime, EASA Part 66 Regulation, which is one of the safety critical areas for aviation regulation):

- India: the Directorate General of Civil Aviation (DGCA), Civil Aviation Requirement (CAR) 66 for Aircraft Maintenance Engineer (AME) licensing;

- Hong Kong: the Civil Aviation Department (CAD) Hong Kong Aviation Requirements (HKAR) 66 for Aircraft Maintenance Licensing (AML);

- Malaysia: the Department of Civil Aviation (DCA) DCAM Part-66 for Aircraft Maintenance License (AML);

- Singapore: the Civil Aviation Authority of Singapore (CAAS) Airworthiness Requirement Part 66 for Aircraft Maintenance Licensing (AML). 


\section{Collaboration}

As the civil aviation segment is more open and global, several nations have benefitted through collaboration and improved their airworthiness enforcement capabilities through expert guidance from countries that are well advanced in their airworthiness programmes. Here are some examples:

\section{The European Union - China Civil Aviation Project (EUCCAP)}

The EUCCAP is a technical assistance project partnership between the European Union and the Government of the People's Republic of China with the beneficiary being the Civil Aviation Administration of China (CAAC) (STI China 2014). This project begun in 2004 and aims to support the CAAC through capacity building, training, sharing of best practices and streamlining of civil aviation regulations and standards regarding safety, including airworthiness, in relation to international standards.

In the area of airworthiness, the EUCCAP has developed the "train-the-trainers" programme that directly addresses capacity constraints in the Chinese civil aviation sector in the area of safety management and airworthiness oversight. Training then can be provided through accredited training programmes in cooperation with civil aviation universities around China, allowing for a larger pool of airworthiness inspectors, inline with the growing number of aircraft operations in the region.

\section{Indonesia Directorate General of Civil Aviation (DGCA) - Australia Civil Aviation Safety Authority (CASA)}

Since 2007, Australia has been working closely with Indonesia on aviation safety issues under the Australian Government funded programme Indonesia Transport Safety Assistance Package (ITSAP).

The purpose of ITSAP is to assist Indonesia in regulating and promoting aviation safety in line with international standards and recommendations as well as conventional safety management practices, consistent with the priorities of the Indonesian Government.

The support provided to Indonesia is in accordance with a memorandum of understanding and cooperation in the transport sector between the governments of Australia and Indonesia, with each country recognising the impact of collaboration between the two neighbours.

The Civil Aviation Safety Authority of Australia (CASA) has played a key role in the delivery of the ITSAP programme. This includes provision of extensive technical training, safety promotion and assistance with development of regulation and guidance material (McCormick 2013).
CASA also works closely with the Indonesian Directorate General of Civil Aviation (DGCA) on key safety oversight issues for Indonesia, such as development of a consistent framework for enforcing airworthiness as well as other aspects, certification of the new Indonesian single air navigation service provider and delivering of safety promotion workshops on continuing airworthiness, runway excursions and mountainous terrain operations (CASA 2013).

\section{Military Airworthiness Authorities (MAA)}

Although there is no global common guidance in the military domain, nations can take a page out of civil collaboration highlighted above. Such examples are already evident in Western military powers such as the militaries of the United States, Canada, the United Kingdom, France and Australia. These nations participate in global forums aimed at establishing common regulatory ground that allows them to share their airworthiness principles and some of their relevant strengths and weaknesses.

Another platform for collaboration on military airworthiness issues is the Military Airworthiness Authorities Forum (MAWA). MAWA was established under the banner of the European Defence Agency (EDA), of the European Union (EU), and is focused on "Building upon the foundations of military airworthiness harmonisation in order to realise future benefits" (EDA 2013). The Forum brings together 95 military airworthiness experts from European Member States, governmental organisations, aerospace industry and the European Aviation Safety Agency as well as representatives from the Asia-Pacific region such as the Republic of Korea and Singapore.

Individually, nations can regulate airworthiness in the military domain through an independent overarching body that has oversight over the aircraft operated by a nation's armed forces (Purton et al. 2014b, 2014c).

\section{Malaysia Directorate General Technical Airworthiness (DGTA)}

The Malaysian Government recognised the need to have an independent organisation to oversee airworthiness for non-civil state registered aircraft. The establishment of the DGTA authorises this agency to become a state agency responsible for regulating the technical airworthiness of state-registered aircraft (DGTA 2015). The DGTA is also responsible for implementing a management system for operational airworthiness and technical airworthiness.

The establishment of DGTA provides a management system and regulatory framework for state technical airworthiness, which is achieved based on its role as a Technical Airworthiness Authority (TAA) and Technical Airworthiness Regulator (TAR) (DGTA 2015). 


\section{Conclusions}

Aviation is a very dynamic industry with fast, widespread changes over time. The Asian region has experienced wide-spread growth on monumental levels never seen before, which has proved to be challenging for airworthiness inspectors and regulators in the civil aviation area. The influx of operating aircraft in the region has also resulted in challenges in ensuring airworthiness and regulating continued airworthiness, and its impact on aviation safety. This growth has also affected the military aviation sector, with the military balance in the region constantly shifting amid heightened tensions.

With every challenge, comes a solution and collaboration between different regulatory organisations is one of those solutions. Collaboration is vital for learning about best practices and there is no better way of learning that to learn from an organisation that has executed those practices safely and efficiently. The sharing of information is a very powerful tool that paves the way for a much safer industry. Such collaborations have evidently had successful outcomes as displayed by the likes of the mirroring of the EASA system by many Asian countries, as well as the EUCCAP and the CASA-DGCA partnership. ICAO has also played a crucial role in consolidating international standards regarding airworthiness regulations by providing individual states with recommendations and more importantly guidance on regulations that shape safety.

Military airworthiness authorities also have the opportunity to collaborate, especially with allies and strategic partners. This enhances current military airworthiness regulations and further brings military regulations closer to civil requirements. Although the risks involved in military operations do not allow civil regulations to be adopted as a whole, there are more commonalities than differences, and this is especially important to ensure the safe operations of all aircraft in airspace or at aerodromes where both civil and military aircraft share operations.

\section{Acknowledgments}

The author would like to acknowledge the valuable feedback received from Dr Kyriakos I. Kourousis, Senior Lecturer in Aircraft Maintenance \& Airworthiness.

\section{References}

Civil Aviation Safety Authority of Australia (CASA). 2013. External engagement. CASA Annual Report 2011-12 [online], [cited 1 May 2015]. Available from Internet: http://www. casa.gov.au/scripts/nc.dll?WCMS:STANDARD:1001:p $\mathrm{c}=$ PC_101124

Chew, L. L. 2013. Personal interview given on 18 December 2013. Department of Civil Aviation Malaysia.

De Florio, F. 2011 Airworthiness: an introduction to aircraft certification. UK: Butterworth-Heinemann.

http://dx.doi.org/10.1016/b978-0-08-096802-5.10002-9
Directorate General Technical Airworthiness (DGTA). 2015. About us: Background [online], [cited 1 May 2015]. Available from Internet: http://www.dgta.gov.my

Eran-Tasker, M. 2013. Personal interview given on 20 December 2013. Association of Asia Pacific Airlines (AAPA).

European Aviation Safety Agency (EASA). 2015 [online], [cited 1 May 2015]. Available from Internet: https://www. easa.europa.eu/the-agency

European Defence Agency (EDA). 2013. Military airworthiness [online], [cited 7 May 2015]. Available from Internet: http://www.eda.europa.eu/docs/default-source/eda-publications/military-airworthiness_web

Federal Aviation Administration (FAA). 2013. International Aviation Safety Assessments (IASA) Program [online], [cited 1 May 2015]. Available from Internet: http://www.faa.gov/ about/initiatives/iasa/

Frost \& Sullivan. 2013. North America diminishing in importance for the global fixed-wing military aircraft market, notes Frost \& Sullivan. Global Fixed Wing Military Aircraft NC82-16. Frost \& Sullivan.

Herdman, A. 2013. Asia Pacific Aviation: challenges and opportunities, in Presentation to AAPA $57^{\text {th }}$ Assembly of Presidents, November 2013, Hong Kong [online], [cited 1 May 2015]. Available on Internet: http://www.aapairlines. org/resource_centre/AAPA_SP_AP57_DG_Presentation_15Nov13.pdf

International Civil Aviation Organisation (ICAO). 2006. Convention on International Civil Aviation - Doc 7300 [online], [cited 7 May 2015]. Available from Internet: http://www. icao.int/publications/pages/doc7300.aspx

International Civil Aviation Organisation (ICAO). 2013. Safety Report [online], [cited 7 May 2015]. Available from Internet: http://www.icao.int/safety/documents/icao_2013safety-report_final.pdf

McCormick, J. 2013. Working in collaboration to enhance aviation safety, in Safety in Aviation - Asia Conference 2013, 7-8 May 2013, Singapore [online], [cited 1 May 2015]. Available from Internet: http://www.casa.gov.au/scripts/ nc.dll?WCMS:STANDARD::pc=PC_101454

Purton, L.; Kourousis, K. 2013. Military airworthiness management frameworks: a critical review, Procedia Engineering 80: 545-564. http://dx.doi.org/10.1016/j.proeng.2014.09.111

Purton, L.; Clothier, R.; Kourousis, K. 2014a. Assessment of technical airworthiness in military aviation: implementation and further advancement of the Bow-tie model, Procedia Engineering 80: 529-544. http://dx.doi.org/10.1016/j.proeng.2014.09.110

Purton, L.; Kourousis, K.; Clothier, R.; Massey, K. 2014b. Mutual recognition of national military airworthiness authorities: a streamlined assessment process, International Journal of Aeronautical and Space Sicences 15(1): 54-62. http://dx.doi.org/10.5139/IJASS.2014.15.1.54

Purton, L.; Clothier, R.; Kourousis, K.; Massey, K. 2014c. The PBP Bow-tie framework for the systematic representation and comparison of military regulatory frameworks, The Aeronautical Journal 118(1210): 1433-1452.

STI China. 2014. Science, technology and innovation performance of China: D9, Final Report [online], [cited 7 May 2015]. Available from Internet: http://eeas.europa.eu/ delegations/china/documents/eu_china/research_innovation/4_innovation/sti_china_study_full_report.pdf

Trew, T.; Trigunarsyah, B.; Coffey, V. 2013 Organizational culture in airworthiness management programmes: extending an existing measurement model, Engineering Project Organisational Journal 3(3): 154-167. http://dx.doi.org/10.1080/21573727.2013.772509 